\title{
The Use of Social Media for Health Research Purposes: Scoping Review
}

Charline Bour ${ }^{1}, \mathrm{MSc}$; Adrian Ahne ${ }^{2,3}, \mathrm{MSc}$; Susanne Schmitz ${ }^{4}$, PhD; Camille Perchoux ${ }^{5}, \mathrm{PhD}$; Coralie Dessenne ${ }^{1}$; Guy Fagherazzi ${ }^{1}$, MSc, PhD

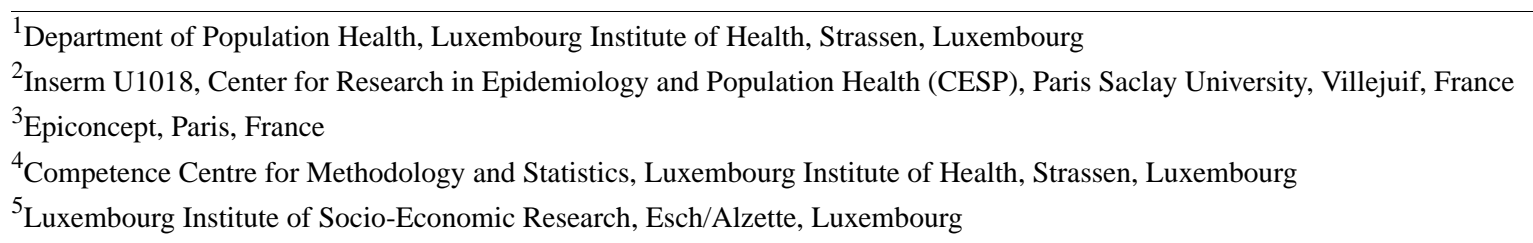

Corresponding Author:

Guy Fagherazzi, MSc, PhD

Department of Population Health

Luxembourg Institute of Health

1 A-B Rue Thomas Edison

Strassen, 1445

Luxembourg

Phone: 35226970457

Fax: 35226970719

Email: guy.fagherazzi@lih.lu

Related Article:

Comment in: https://www.jmir.org/2022/1/e35286

\section{Abstract}

Background: As social media are increasingly used worldwide, more and more scientists are relying on them for their health-related projects. However, social media features, methodologies, and ethical issues are unclear so far because, to our knowledge, there has been no overview of this relatively young field of research.

Objective: This scoping review aimed to provide an evidence map of the different uses of social media for health research purposes, their fields of application, and their analysis methods.

Methods: We followed the scoping review methodologies developed by Arksey and O'Malley and the Joanna Briggs Institute. After developing search strategies based on keywords (eg, social media, health research), comprehensive searches were conducted in the PubMed/MEDLINE and Web of Science databases. We limited the search strategies to documents written in English and published between January 1, 2005, and April 9, 2020. After removing duplicates, articles were screened at the title and abstract level and at the full text level by two independent reviewers. One reviewer extracted data, which were descriptively analyzed to map the available evidence.

Results: After screening 1237 titles and abstracts and 407 full texts, 268 unique papers were included, dating from 2009 to 2020 with an average annual growth rate of $32.71 \%$ for the $2009-2019$ period. Studies mainly came from the Americas (173/268, $64.6 \%$, including 151 from the United States). Articles used machine learning or data mining techniques (60/268) to analyze the data, discussed opportunities and limitations of the use of social media for research (59/268), assessed the feasibility of recruitment strategies (45/268), or discussed ethical issues (16/268). Communicable (eg, influenza, 40/268) and then chronic (eg, cancer, 24/268) diseases were the two main areas of interest.

Conclusions: Since their early days, social media have been recognized as resources with high potential for health research purposes, yet the field is still suffering from strong heterogeneity in the methodologies used, which prevents the research from being compared and generalized. For the field to be fully recognized as a valid, complementary approach to more traditional health research study designs, there is now a need for more guidance by types of applications of social media for health research, both from a methodological and an ethical perspective.

International Registered Report Identifier (IRRID): RR2-10.1136/bmjopen-2020-040671 
(J Med Internet Res 2021;23(5):e25736) doi: 10.2196/25736

\section{KEYWORDS}

social media; public health; epidemiology; research; health; medical; social networking; infodemiology; eHealth; text mining

\section{Introduction}

\section{Social Media Background}

Social media (SM) refer to new forms of media that involve interactions between users [1] in personal (eg, Facebook) or more professional (eg, LinkedIn) ways. In 2010 in the United States, $80 \%$ of adults used the internet to search for health-related information, and $11 \%$ of SM users posted comments, queries, or information about health or medical content [2]. Every user activity on the internet generates a unique digital footprint that can be collected for health research [3]. However, SM are not only used in a personal way. Indeed, academics are also increasingly using SM to share their work and disseminate their findings [4].

\section{Opportunities for Health Research}

Since the creation of SM in 2004-2005 and with 3.81 billion active social media users in April 2020 [5], concepts like infodemiology and infoveillance have emerged. The term "infodemiology" refers to the science of using the internet to improve public health, while "infoveillance" refers to the science of syndromic surveillance using the internet [6]. These opportunities have been seized through the years in order to create new methodologies for health research to cope with the issues raised by traditional methods (eg, difficulty of recruitment [7]).

\section{Scoping Review Contextualization}

Previous scoping and systematic reviews have already been published about the different uses of SM for health research. However, they were either focusing on a specific type of SM (eg, blogs [8]), on a specific field of health research (eg, child maltreatment [9]), or on a specific methodology (eg, recruitment of study participants $[10,11])$. Other reviews discussed the overall use of SM for health research [12,13] but did not provide any insights on the analysis techniques or the ethical issues. Besides, the COVID-19 pandemic has sped things up and pushed research to be done online, leveraging existing data for disease surveillance purposes, which makes the present work particularly timely and needed for better structuration of the field [14]. The research field on social media and health is relatively young and therefore lacks structures and guidelines. In the light of the above, it seemed important to map the different uses of social media for health research. Our work will directly contribute to the general effort of acknowledging the potential of this research field and will help to identify the main limitations to tackle in the future.

\section{Review Questions}

The overall research questions were as follows: (1) How have SM modified or complemented traditional health research? (2) What are the different fields of application of this approach? (3) What are the different methodologies for SM data analysis?

\section{Methods}

\section{Overview}

This scoping review followed the methodological framework introduced by Arskey and O'Malley in 2005 [15] and the methodology manual published by the Joanna Briggs Institute for scoping reviews [16]. It is reported in accordance with the Preferred Reporting Items for Systematic Reviews and Meta-analyses Extension for Scoping Review (PRISMA-ScR) guidelines [17]. The methods have been previously detailed in a research protocol [18].

\section{Search Strategy}

An initial literature search was first manually conducted on PubMed/MEDLINE to identify the health research fields in which SM are mostly used and developed. We searched for the term "social media" in the Medical Subject Headings (MeSH) Terms (words or phrases selected to represent particular biomedical concepts) as it gathers all papers discussing the use of at least one example of social media. For instance, this MeSH Term also includes articles that mention Facebook or Twitter without referring directly to "social media." We considered the term "health research" as all kinds of research performed to learn more about human health, prevent or treat disease, test ideas, improve treatments, and answer questions. Then, the literature search was performed through PubMed/MEDLINE and Web of Science. The search strategy, highlighted in Textbox 1, included two sets of search terms: (1) one linked with SM (eg, social media) and (2) one linked with research (eg, health research, biomedical research). In order to capture the evolution of SM uses for health research over the years, databases were searched between January 1, 2005, and April 9, 2020. The term "social network" was also searched, as it is often misused as a synonym of SM. An additional list of 5 relevant articles [19-23] was manually searched to identify any other potentially relevant articles not yet captured. These articles were chosen in order to retrieve more articles about infodemiology, ethical issues, or the use of SM data. A snowball searching technique was adopted with these 5 articles in which citations within articles were searched and kept if relevant to the review. 
Textbox 1. Inclusion criteria, exclusion criteria, and search strings.

\author{
Inclusion criteria \\ - $\quad$ written in English \\ - $\quad$ published between January 1, 2005, and April 9, 2020 \\ - dealt with the use of social media by researchers \\ Exclusion criteria \\ - not about health research \\ - $\quad$ not related to social media (eg, social network analysis) \\ - not about human subjects \\ - no relevant information (eg, methodology) about the use of social media for health research \\ - no relevant characteristics of social media
}

\title{
Search string in PubMed
}

(((“Social Media”[MH]) OR (“Social Media”[TW])) AND ((“Biomedical research”[MH]) OR ("Medical research”[TW] OR "Biomedical research”[TW]) OR ("Health research"[TW] OR "Health services research"[TW]))) OR ((("Social networking"[MH]) OR ("Social network"[TW] OR "Social networks"[TW] OR "Social networking"[TW])) AND ((“Biomedical research"[MH]) OR ("Medical research"[TW] OR "Biomedical research" [TW]) OR ("Health research"[TW] OR "Health services research"[TW]))) Filters: Journal Article; Publication date from 2005/01/01 to 2020/04/09; Humans; English

\section{Search string in Web of Science}

(TS=“Social Media" OR TS= "Social networking" OR TS= "Social network" OR TS= "Social networks") AND (TS="Biomedical research" OR TS="Medical research" OR TS="Health research" OR TS="Health services research") AND (PY=(2005-2020)) AND (LANGUAGE: (English)) Indexes=SCI-EXPANDED, SSCI, A\&HCI, CPCI-S, CPCI-SSH, ESCI Timespan=All years

\section{Eligibility Criteria}

This review was guided by the "Population, Concept, Context" framework suggested by the Joanna Briggs Institute [24]. We did not have any restriction about the population; we took any relevant publications regardless of the age, the origin, or the gender of the studied populations. The concept was the use of social media and the context was health research. The eligibility criteria were any journal article that described the use of social media platforms or social media data for health or medical research purposes. We excluded articles that were not directly related to research from our review, such as those on the use of social media among patients, patient associations or communities, organizations, or health care professionals for their day-to-day practice. Grey literature and studies about nonhuman subjects were excluded as well. Documents related to the mining of social media data to detect prescription drug misuse and abuse as well as those related to the use of machine learning methodologies to analyze data were eligible for inclusion. We included full texts that reported on at least one of the following outcomes: (1) SM data analysis, (2) recruitment through SM, (3) methodology for SM research, and (4) ethical issues of using SM for health research. Only English-language articles were retained. The inclusion and exclusion criteria and the search strings are summarized in Textbox 1.

\section{Study Selection Process}

A 2-step screening was performed after duplicate removal. First, titles and abstracts were screened in order to define the eligibility of each article. Publications with title or abstract not meeting the eligibility criteria were excluded. Then, the full texts having passed the first step were screened, and only articles meeting the eligibility criteria were kept. All screening levels were conducted with CADIMA [25], a free web tool to facilitate the conduct and documentation of literature reviews [26]. Two reviewers screened articles (GF, CB) independently, and consistency checks were performed thanks to CADIMA.

\section{Data Extraction}

Data were abstracted on (1) the country of origin, (2) the aims of the study (eg, to map ethical issues when using SM for health research), (3) the type of study (eg, recruitment feasibility assessment), (4) the research field (eg, mental health research), (5) the studied population (eg, adolescents), (6) the type of SM (eg, Facebook), (7) the methodology (eg, paid advertisement), (8) the outcomes of the study (eg, efficiency of recruitment via SM), and (9) the key findings for our scoping review (eg, possibility to recruit on SM). Data were extracted and cleaned by a first reviewer (CB), then verified and approved by a second reviewer (GF).

\section{Methodological Quality Appraisal}

Because this is a scoping review, we did not appraise methodological quality or risk of bias of the included articles.

\section{Analysis and Presentation of Results}

We conducted a descriptive analysis of the characteristics of the included literature. We described the included articles according to the journal of publication, publication date, country of origin (location of the corresponding author), Altmetric score (automatically calculated weighted count of all of the attention a research output has received) [27], type of SM, type of population, and type of disease studied. We decided to focus on Altmetric score rather than citation counts; as the SM 
research field is still relatively young, traditional citation counts provide a quite conservative approach of a paper's "influence" that is influenced by the size of the research community working on the topic. Thus, Altmetric might be less influenced by the relatively "young" aspect of this research field by giving weight to other dimensions (record of dissemination, influence, impact). All these measures are more nuanced than citation counts alone are able to be $[28,29]$. However, Altmetric scores also have some limitations, as they do not take comparability across journals and platforms into account, and this system can be gamed [30,31].

We categorized the diseases in 7 categories: (1) chronic diseases (eg, diabetes), (2) communicable diseases (eg, influenza), (3) alcohol/smoking (eg, vaping), (4) mental health (eg, depression), (5) lifestyle (eg, nutrition outcomes), (6) drug/medication (eg, drug use disorder), and (7) other (eg, child maltreatment). Descriptive statistics and corresponding plots were computed (n, means, frequencies) with R (version 3.6.3; R Foundation for Statistical Computing).

Figure 1. Flow diagram of the included studies.
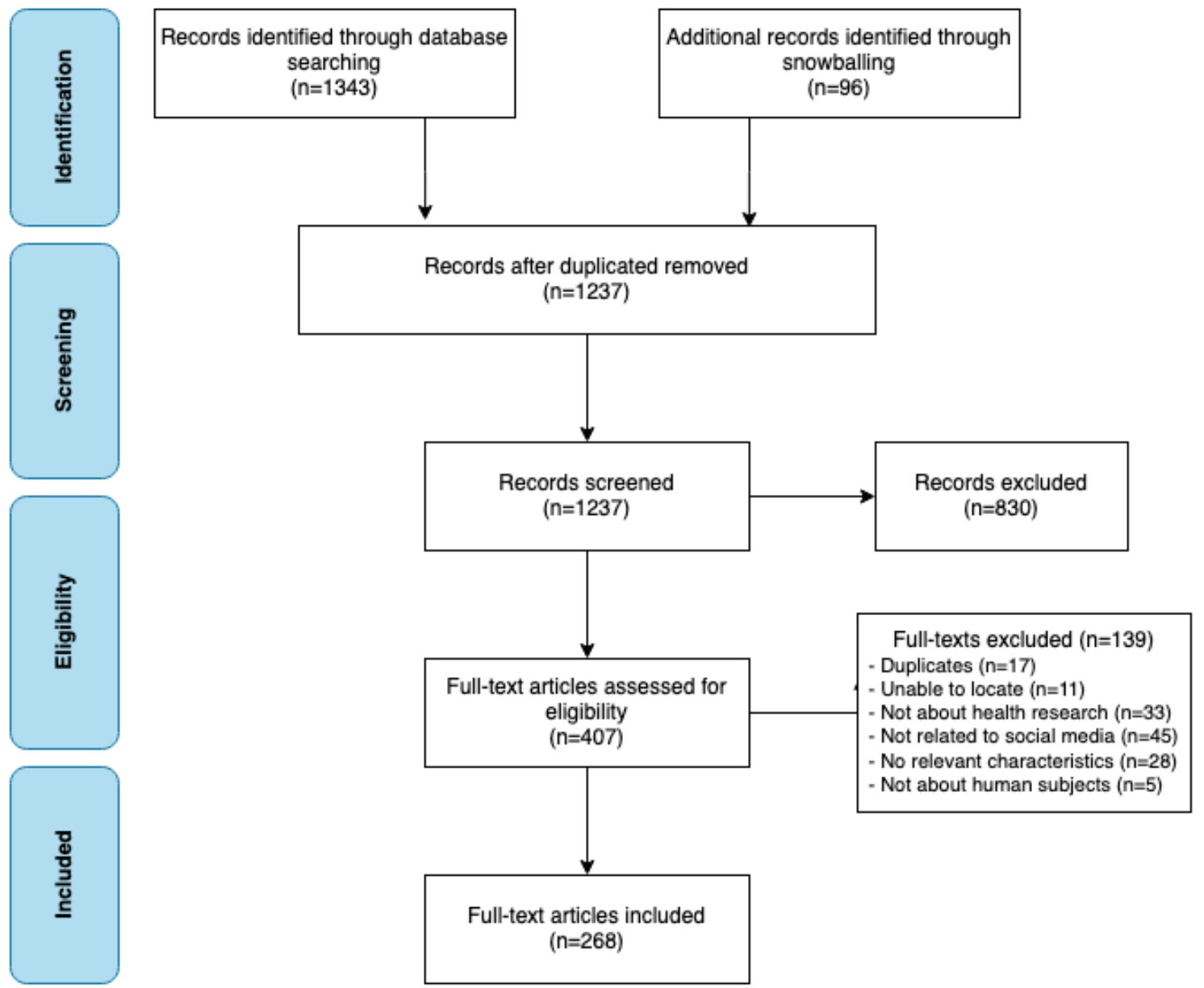

\section{Distribution of Studies}

In all, we included 268 unique records from 155 different journals. Table 1 displays the 10 most common journals in which the included studies were published: 55 (20.5\%) articles

\section{Results}

\section{Search Results}

The initial search conducted in April 2020 revealed 1343 results. An additional 96 articles were retrieved through a snowballing technique based on 5 relevant articles [16-20]. This resulted in a total of 1439 articles, and duplicates $(n=202)$ were removed. Then, 1237 titles and abstracts were screened, which led to the exclusion of 830 articles. Overall, 407 studies were included to screen as full - text papers, of which 139 were excluded. The main reasons for exclusion were that the study (1) did not contain relevant characteristics of SM for health research $(n=28)$, (2) did not relate to SM ( $n=45)$, or (3) was not about health research $(n=33) .268$ studies were included in the analyses. Figure 1 shows the flow diagram of the article selection. Lastly, Multimedia Appendix 1 displays the characteristics of the 268 included studies (author or authors, year of publication, country, title, aim of the study, type of social media, studied population and disease). were published in the Journal of Medical Internet Research or sister journals JMIR Research Protocols and JMIR Public Health and Surveillance. PLOS ONE is the second most common journal with $10(3.7 \%)$ articles. 
Table 1. Top 10 most common journals publishing work using social media for health research purposes.

\begin{tabular}{ll}
\hline Name of the journal & Articles, $\mathrm{n}(\%)$ \\
\hline Journal of Medical Internet Research & $39(14.6)$ \\
PLoS ONE & $10(3.7)$ \\
JMIR Research Protocols & $9(3.4)$ \\
JMIR Public Health and Surveillance & $7(2.6)$ \\
American Journal of Public Health & $5(1.9)$ \\
The American Journal of Bioethics & $5(1.9)$ \\
BMC Medical Informatics and Decision Making & $4(1.5)$ \\
International Journal of Environmental Research and Public Health & $4(1.5)$ \\
PLoS Computational Biology & $4(1.5)$ \\
Digital Health & $3(1.1)$ \\
\hline
\end{tabular}

A total of 1025 authors took part in the writing of the included studies. Figure S1 in Multimedia Appendix 2 provides the coauthorship network of all these authors. The largest set of connected authors included 57 authors and shown in Figure S2 in Multimedia Appendix 2).

Even though our research date range was from 2005 to 2020 , none of the 268 included articles are dated before 2009. In Table 2 , it can be seen that the number of publications is growing through the years, corresponding to an average annual growth rate of $32.7 \%$ for the $2009-2019$ period. This suggests that the field of health research supplemented by SM has gained interest for the last 11 years. Earlier studies concentrated more on the use of SM for health research in general and the opportunities for the study of communicable diseases. The most recent studies more frequently included recruitment strategies and methodologies. Table 3 displays the distribution of articles by the continent of publication. Most articles were from the Americas (173/268, 64.6\%, including 151/173, 87.3\% from the United States), $18.7 \%$ were from Europe (50/268), $11.6 \%$ were from Oceania (31/268), 4.9\% were from Asia (13/268), and $0.4 \%$ were from Africa (1/268).

Table 2. Distribution of publications by year of publication.

\begin{tabular}{ll}
\hline Year & Publications, $\mathrm{n}$ \\
\hline 2009 & 2 \\
2010 & 3 \\
2011 & 7 \\
2012 & 5 \\
2013 & 20 \\
2014 & 26 \\
2015 & 34 \\
2016 & 37 \\
2017 & 42 \\
2018 & 36 \\
2019 & 45 \\
2020 (Jan 1-Apr 9) & 11 \\
\hline
\end{tabular}

Table 3. Distribution of publications by geographic location (as assessed by the location of the corresponding author).

\begin{tabular}{ll}
\hline Geographic location & Publications, $\mathrm{n}$ \\
\hline Africa & 1 \\
The Americas & 173 \\
Asia & 13 \\
Europe & 50 \\
Oceania & 31 \\
\hline
\end{tabular}




\section{Social Media}

Among all the retrieved articles, $57.8 \%$ (155/268) used or described at least one specific type of SM. From these articles, as can be seen in Table 4, 42.6\% (66/155) were based on
Twitter, 34.2\% (53/155) on Facebook, and 11.0\% (17/155) on several SM (eg, combining Facebook, Instagram, and Snapchat [32]). The remaining $12.3 \%$ (19/155) were distributed between Instagram, Reddit, forums, blogs, Weibo, and YouTube.

Table 4. Distribution of publications by social media $(\mathrm{N}=155)$.

\begin{tabular}{ll}
\hline Type of social media & Publications, $\mathrm{n}$ \\
\hline Blogs & 2 \\
Facebook & 53 \\
Forums & 3 \\
Instagram & 5 \\
Reddit & 5 \\
Several types & 17 \\
Twitter & 66 \\
Weibo & 2 \\
YouTube & 2 \\
\hline
\end{tabular}

\section{Focused Populations}

A total of $80.2 \%(215 / 268)$ of included articles did not focus on any specific population. In articles that studied a specific subpopulation $(n=53)$, youth was the most common one $(34 / 53$,

$64 \%)$, followed by women $(7 / 53,13 \%)$, families $(5 / 53,9 \%)$, men $(1 / 53,2 \%)$, and other $(6 / 53,11 \%)$, as shown in Table 5. The "Other" category gathered adults (2/6), Chinese migrants $(1 / 6)$, elderly people (1/6), emergency nurses (1/6), and researchers $(1 / 6)$.

Table 5. Distribution of publications per studied population ( $\mathrm{N}=53)$.

\begin{tabular}{ll}
\hline Studied population & Publications, $\mathrm{n}$ \\
\hline Youth & 34 \\
Women & 7 \\
Families & 5 \\
Men & 1 \\
Other & 6 \\
\hline
\end{tabular}

\section{Domain of Health Research}

In addition, $45.1 \%(121 / 268)$ of publications dealt with a specific disease or condition (the remaining articles usually dealt with the use of SM for health research in general or with methodology). Indeed, as shown in Table 6, 33.1\% (40/121) of articles studied communicable diseases, $19.8 \%$ (24/121) studied chronic diseases, $15.7 \%$ (19/121) studied lifestyle (eg, nutrition outcomes), 13.2\% (16/121) studied other conditions (eg, drug use disorder), $9.9 \%$ (12/121) studied alcohol/smoking (eg, vaping), and $8.3 \%(10 / 121)$ studied mental health (eg, depression).

Table 6. Distribution of publications by studied disease type ( $\mathrm{N}=121)$.

\begin{tabular}{ll}
\hline Studied disease type & Publications, $\mathrm{n}$ \\
\hline Alcohol/smoking & 12 \\
Chronic diseases & 24 \\
Communicable diseases & 40 \\
Lifestyle & 19 \\
Mental health & 10 \\
Other & 16 \\
\hline
\end{tabular}




\section{Communicable Diseases}

Among articles that discussed communicable diseases, influenza was the primary studied disease $(18 / 40,45 \%)$, followed by HIV $(8 / 40,20 \%)$ and human papillomavirus $(3 / 40,8 \%)$.

\section{Chronic Diseases}

Among articles that discussed chronic diseases, a quarter studied cancer $(6 / 24,25 \%)$, followed by diabetes $(5 / 24,21 \%)$, cardiovascular diseases (eg, congenital heart disease, 3/24, $12 \%)$, and obesity $(2 / 24,8 \%)$.

\section{Dissemination}

As highlighted in Figure 2, some papers stood out and could be considered important in the recent field of health research on social media.

Figure 2. Distribution of Altmetric scores by health research area. Corresponding publications to the indicated Altmetric scores: Alcohol/Smoking: 26 [33]; Chronic diseases: 94 [34], 263 [35], 1090 [36]; Communicable diseases: 268 [37]; Mental health: 47 [38]; Lifestyle: 365 [39]; Other: 59 [40], 145

[41]. General corresponds to the Altmetric scores of all studies.
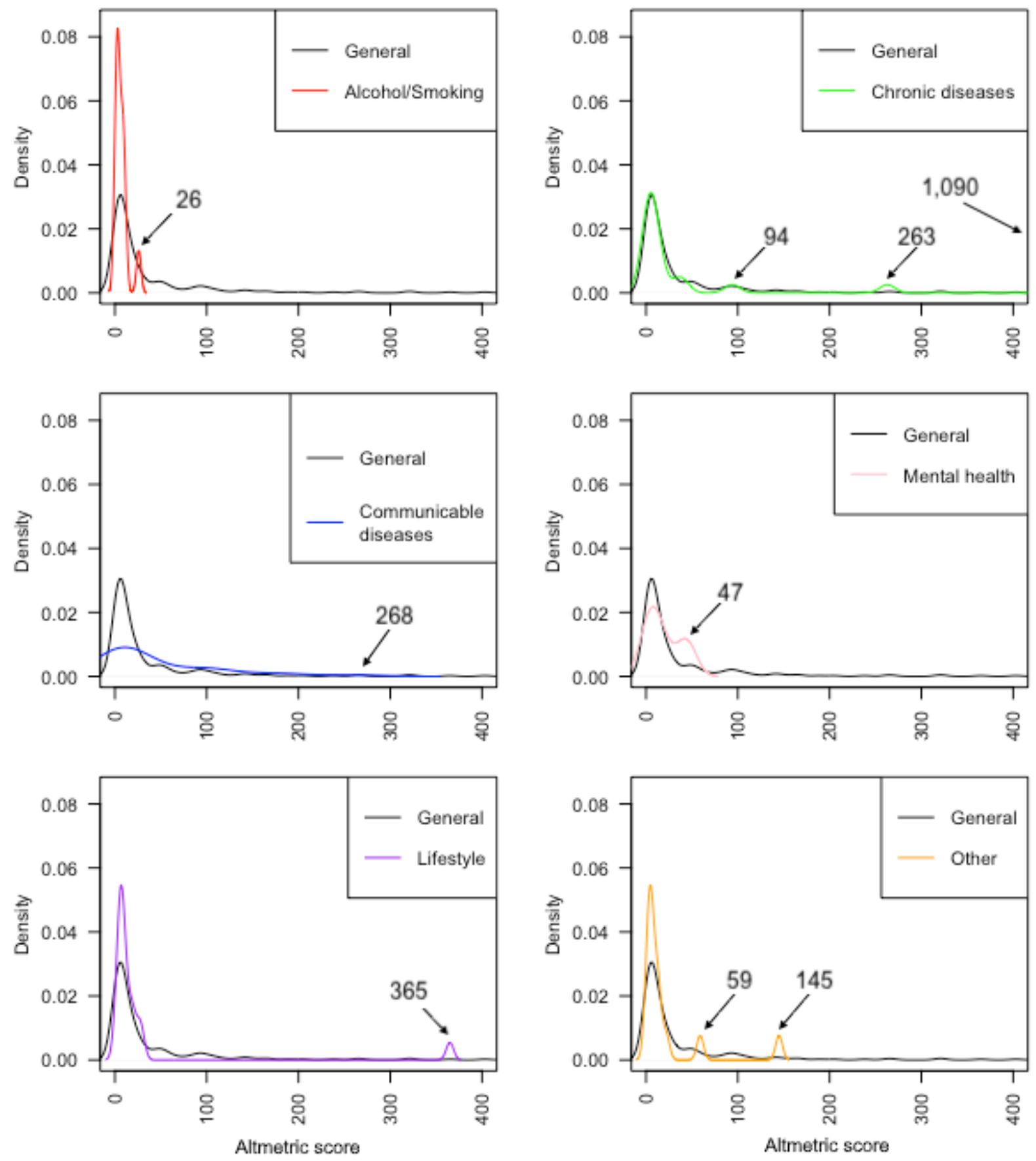

\section{Type of Studies}

Among all included studies, 22.4\% (60/268) described the use of machine learning and data mining techniques, $22.0 \%$ (59/268) discussed the opportunities and limitations of the use of SM for

research, $16.8 \%(45 / 268)$ assessed the feasibility of recruitment strategies on SM, 6.0\% (16/268) discussed the ethical issues when using SM for health research, 5.2\% (14/268) gave methodologies for health research, and $4.9 \%$ (13/268) illustrated the use of SM for dissemination. Guidelines for recruitment 
(9/268, 3.4\%), interventions of prevention $(6 / 268,2.2 \%)$, crowdfunding $(4 / 268,1.5 \%)$, sentiment analysis $(4 / 268,1.5 \%)$, data anonymization $(2 / 268,0.7 \%)$, and crowdsourcing $(2 / 268$, $0.7 \%$ ) were also considered.

\section{Machine Learning and Other Techniques}

Machine learning techniques included text mining (17/60, 28\%), natural language processing $(15 / 60,25 \%)$, data mining $(12 / 60$, $20 \%)$, classification $(10 / 60,17 \%)$, topic modelling $(4 / 60,7 \%)$, deep learning $(1 / 60,2 \%)$, and social network analysis $(1 / 60$, $2 \%)$. In particular, support vector machine (17/60, 28\%), logistic regression $(11 / 60,18 \%)$, latent Dirichlet allocation $(5 / 60,8 \%)$, convolutional neural network $(5 / 60,8 \%)$, random forests $(4 / 60$, $7 \%)$, decision trees $(4 / 60,7 \%)$ and n-grams $(64 / 60,7 \%)$ are the most used models. Stacked linear regression, Bayesian network algorithm, nonnegative matrix factorization, stochastic gradient, learning vector quantization, and recurrent neural networks represent $2 \%(1 / 60)$ each. Lastly, these techniques were mostly used for data coming from Twitter $(38 / 60,63 \%)$ and Reddit $(3 / 60,5 \%)$.

\section{Recruitment Strategies}

Studies assessing recruitment strategies' feasibility applied paid advertisement (36/45, 80\%), free advertisement (eg, posting in relevant Facebook groups [42]) (6/45, 13\%), and the combination of both advertisements $(3 / 45,7 \%)$. Paid recruitment strategies included designing the ad, targeting the right audience with Facebook Ads Manager and measuring the impacts with Facebook Analytics [43]. Moreover, 64\% (29/45) of studies considered SM recruitment to be effective (time-effective and efficient to recruit populations). Paid advertisement was evaluated as cost-effective in $83 \%(30 / 36)$ of studies and too costly in $6 \%(2 / 36)$. We found out that $80 \%(36 / 45)$ of recruitment was carried out on Facebook, 9\% (4/45) on both Facebook and Twitter, and 9\% (4/45) on more than two types of SM (eg, Facebook, Twitter, Craigslist, Tumblr, LinkedIn [44]). Lastly, a third of recruitment strategies included providing incentives to participants (eg, gift cards).

\section{Ethical Issues}

Ethical issues were usually mentioned but not investigated in detail. When the article focused on ethical issues $(n=16)$, the main ethical issues raised were getting consent of online users $(15 / 16,94 \%)$, protecting the privacy of users $(14 / 16,88 \%)$, preserving confidentiality $(9 / 16,56 \%)$, potential harms to participants $(9 / 16,56 \%)$, preserving of anonymity $(8 / 16,50 \%)$, securing data $(7 / 16,44 \%)$, transparency of the research $(7 / 16$, $44 \%)$, application of guidelines $(7 / 16,44 \%)$, representativeness and self-selection bias $(5 / 16,31 \%)$, and the risk of double accounts $(2 / 16,12 \%)$.

\section{Discussion}

\section{Principal Findings}

The overarching aim of this review was to scope the literature for evidence on the use of SM for health research. We were able to include 268 studies. Most of the included articles in this scoping review are dated from 2013 onwards, which is consistent with the worldwide growth of SM use over the last decade [45]. We identified three main SM used for health research: Twitter, Facebook, and Instagram, the most popular platforms in 2020 [46]. The most studied populations are young adults and adolescents. This could be related to the elevated proportion of young people active on SM. In 2018 in the United States, $51 \%$ of teens were on Facebook, $69 \%$ on Snapchat, 72\% on Instagram, and $85 \%$ on YouTube; thus, SM seems to have great potential to focus on the young generations [47]. The majority of the included works focused on both communicable and chronic diseases. The field of SM research is still very young, and this can be seen in the impact that publications have (via the Altmetric score), with the exception of 9 articles. However, it is set to evolve rapidly, and it will be necessary to follow the evolution of the Altmetric scores of the field in the coming years to identify the new major articles.

The fields of application of SM in health research are broad and constantly evolving: as earlier studies concentrate on the study of communicable diseases, most recent studies include recruitment strategies and data collection for infoveillance. First, SM can be used to complement traditional methods. Traditional procedures can meet several limitations. When recruiting a specific population, traditional methods (eg, fliers, advertising) can be expensive or limited in reach [7,48-50]. Complementing them with SM advertisements can cope with these limitations. Second, SM alone show high potential. Studies have concluded that SM paid advertisements can be an efficient and cost-effective tool to recruit [11,51-56]. SM appear not only to facilitate and complement traditional recruitment strategies to reach specific populations but to be efficient as well when used alone [52,57-59], especially to reduce time constraints or to target a large population [60]. Particularly, Facebook can be used to recruit participants of all ages and allows researchers to obtain participant samples similarly representative to those recruited via traditional recruitment methods [11]. Facebook, together with Facebook Ads Manager and Facebook Analytics, are particularly useful to develop and adjust such strategies. Traditional disease surveillance, population surveillance, and epidemiology methodologies can be improved by SM $[21,50,61]$. Pharmacovigilance and the detection of adverse drug reactions on SM proved to be efficient and to reduce time between the online report of an incident and its discovery [62-64]. As the number of SM users is increasing, generated data, or "big data," is expanding. Such data can be collected and studied to improve disease and public health surveillance [65-67] to forecast diseases [68] or to improve research in a medical field $[69,70]$. Along with big data growth, machine learning and data mining techniques such as text mining and natural language processing are constantly evolving and are thus increasingly used in the field of public health research based on SM [71-73]. These techniques can be particularly interesting to analyze social media data and, for instance, to develop sentiment or topic analysis among a specific population $[19,74]$ or to predict epidemics [75]. Twitter is mainly used for such work because Twitter developed a streaming application programming interface. This is a free application that allows easy access to $1 \%$ of all Twitter data in real time, filtered by specific criteria (eg, keywords) [76,77]. Lastly, SM can be directly used by health researchers to support prevention interventions to raise awareness and engage populations [78] 
and to crowdfund by promoting their research on SM. Indeed, crowdfunding can be eased by establishing professional contacts through SM and sharing campaigns [79].

The digitization of public health and clinical research is likely to grow in the years to come. The COVID-19 pandemic has already played a major role in this dynamic. Indeed, social media were not only efficient to spread information and to share diagnostic, treatment, and even follow-up protocols [80-82] but also to develop infoveillance studies to help characterize disease distribution and behaviors critical to the early stages of an outbreak $[83,84]$ and to recruit participants in order to collect large-scale data within a short time period [85].

Still, the use of SM features and SM data for health research induces several ethical issues and limitations. Online data, such as those from Twitter, are often considered to be public, and user consent is not provided for collecting it. Moreover, ensuring privacy protection of a data set when anyone has access to vast amounts of public information is difficult because data could be reidentified $[86,87]$. Safety features should be used to protect users' personal and sensitive information [20] and to protect users from dangerous or fake content posted by detractors, chatbots, or social media trolls (people who purposely provoke other SM users) [88]. These kinds of behaviors can also be oriented to researchers themselves and demotivate them. Moreover, data can represent only certain users' characteristics due to researchers' self-selection or to coverage issues of underserved populations or minority groups who are disproportionately absent online (eg, older adults). This can bias the representativeness of the sample and consequently bias the findings and prevent from any generalizability [89,90]. However, it is possible to multiply platforms (cross-platforms) or to combine with other recruitment methods to minimize such bias [91]. When recruiting and providing incentives, users might be tempted to participate multiple times. Researchers should ensure that the study allows only one response from a given IP address [92,93]. A few guidelines and frameworks have already been created to guide health researchers in using social media and prevent such issues [94-98].

\section{Strengths and Limitations of This Scoping Review}

The present work used a rigorous scoping review methodology from the manual by the Joanna Briggs Institute [16] throughout the entire process. It was guided by a previously published protocol [18]. To ensure a broad search of the literature, the search strategy included two electronic bibliographic databases and the snowball technique. There are some limitations to our scoping review process. We may not have identified all relevant articles in the published literature despite attempts to be as comprehensive as possible. We limited our review to documents written in English, which may have led to missed relevant studies. Data were abstracted by one reviewer and verified by a second reviewer because of the important number of included publications.

\section{Conclusion and Recommendations}

Our findings suggest that SM hold high potential to improve and complement existing health research studies. Indeed, some SM features can complement traditional research strategies, and the growing amounts of SM data hold great opportunities in the evolution of infoveillance and infodemiology. For researchers, SM can be an effective tool at almost every step of a study, from the development, ideation, recruitment, and crowdsourcing to the dissemination of findings. Researchers should determine which type of SM best fits their objectives, as Facebook might be better for recruitment and Twitter for data collection, in order to gain time and efficiency. Last but not least, we have observed strong heterogeneity in the approaches used. We therefore recommend taking the existing guidelines into account and carefully thinking about the different ethical issues highlighted in this work before using SM for research.

\section{Acknowledgments}

This work is supported by the Luxembourg Institute of Health.

\section{Authors' Contributions}

CB and GF conducted title, abstract, and full-text screening. CB performed data extraction and data cleaning. GF performed data verification. $\mathrm{CB}$ and GF drafted the manuscript. $\mathrm{CB}, \mathrm{SS}, \mathrm{CD}, \mathrm{GF}, \mathrm{AA}$, and $\mathrm{CP}$ contributed to review and final approval of the manuscript.

\section{Conflicts of Interest}

None declared.

\section{Multimedia Appendix 1}

Overview of the included studies by year, country of origin, aim, population, type of social media and disease. NR: not relevant. [XLSX File (Microsoft Excel File), 73 KB-Multimedia Appendix 1]

\section{Multimedia Appendix 2}

Coauthorship network.

[DOCX File, 12066 KB-Multimedia Appendix 2]

\section{References}


1. Harvey K. Encyclopedia of Social Media and Politics. United States: SAGE; 2014.

2. The Social Life of Health Information, 2011.: Pew Research Center; 2011 May 12. URL: https://www.pewresearch.org/ internet/2011/05/12/the-social-life-of-health-information-2011/ [accessed 2020-06-29]

3. Bidargaddi N, Musiat P, Makinen V, Ermes M, Schrader G, Licinio J. Digital footprints: facilitating large-scale environmental psychiatric research in naturalistic settings through data from everyday technologies. Mol Psychiatry 2017 Feb;22(2):164-169 [FREE Full text] [doi: 10.1038/mp.2016.224] [Medline: 27922603]

4. Bardus M, El Rassi R, Chahrour M, Akl E, Raslan A, Meho L, et al. The Use of Social Media to Increase the Impact of Health Research: Systematic Review. J Med Internet Res 2020 Jul 06;22(7):e15607 [FREE Full text] [doi: 10.2196/15607] [Medline: 32628113]

5. Clement J. Global digital population as of April 2020. URL: https://www.statista.com/statistics/617136/ digital-population-worldwide/ [accessed 2020-05-01]

6. Eysenbach G. Infodemiology and infoveillance: framework for an emerging set of public health informatics methods to analyze search, communication and publication behavior on the Internet. J Med Internet Res 2009;11(1):e11 [FREE Full text] [doi: 10.2196/jmir.1157] [Medline: 19329408]

7. Frandsen M, Thow M, Ferguson SG. The Effectiveness Of Social Media (Facebook) Compared With More Traditional Advertising Methods for Recruiting Eligible Participants To Health Research Studies: A Randomized, Controlled Clinical Trial. JMIR Res Protoc 2016 Aug 10;5(3):e161 [FREE Full text] [doi: 10.2196/resprot.5747] [Medline: 27511829]

8. Wilson E, Kenny A, Dickson-Swift V. Using Blogs as a Qualitative Health Research Tool. International Journal of Qualitative Methods 2015 Dec 11;14(5):160940691561804. [doi: 10.1177/1609406915618049]

9. Schwab-Reese L, Hovdestad W, Tonmyr L, Fluke J. The potential use of social media and other internet-related data and communications for child maltreatment surveillance and epidemiological research: Scoping review and recommendations. Child Abuse Negl 2018 Nov;85:187-201 [FREE Full text] [doi: 10.1016/j.chiabu.2018.01.014] [Medline: 29366596]

10. Topolovec-Vranic J, Natarajan K. The Use of Social Media in Recruitment for Medical Research Studies: A Scoping Review. J Med Internet Res 2016 Nov 07;18(11):e286 [FREE Full text] [doi: 10.2196/jmir.5698] [Medline: 27821383]

11. Thornton L, Batterham P, Fassnacht D, Kay-Lambkin F, Calear A, Hunt S. Recruiting for health, medical or psychosocial research using Facebook: Systematic review. Internet Interv 2016 May;4:72-81 [FREE Full text] [doi:

10.1016/j.invent.2016.02.001] [Medline: 30135792]

12. Taylor J, Pagliari C. Comprehensive scoping review of health research using social media data. BMJ Open 2018 Dec 14;8(12):e022931 [FREE Full text] [doi: 10.1136/bmjopen-2018-022931] [Medline: 30552260]

13. Dol J, Tutelman PR, Chambers CT, Barwick M, Drake EK, Parker JA, et al. Health Researchers' Use of Social Media: Scoping Review. J Med Internet Res 2019 Nov 13;21(11):e13687 [FREE Full text] [doi: 10.2196/13687] [Medline: 31719028]

14. Fagherazzi G, Goetzinger C, Rashid MA, Aguayo GA, Huiart L. Digital Health Strategies to Fight COVID-19 Worldwide: Challenges, Recommendations, and a Call for Papers. J Med Internet Res 2020 Jun 16;22(6):e19284 [FREE Full text] [doi: 10.2196/19284] [Medline: 32501804$]$

15. Arksey H, O'Malley L. Scoping studies: towards a methodological framework. International Journal of Social Research Methodology 2005 Feb;8(1):19-32. [doi: 10.1080/1364557032000119616]

16. Peters MDJ, Godfrey C, McInerney P, Munn Z, Tricco AC, Khalil H. Chapter 11: Scoping Reviews. JBI Reviewer's manual. 2019. URL: https://wiki.jbi.global/display/MANUAL/Chapter+11\%3A+Scoping+reviews [accessed 2020-06-24]

17. Tricco AC, Lillie E, Zarin W, O'Brien KK, Colquhoun H, Levac D, et al. PRISMA Extension for Scoping Reviews (PRISMA-ScR): Checklist and Explanation. Ann Intern Med 2018 Oct 02;169(7):467-473. [doi: 10.7326/M18-0850] [Medline: $\underline{30178033}$ ]

18. Bour C, Schmitz S, Ahne A, Perchoux C, Dessenne C, Fagherazzi G. Scoping review protocol on the use of social media for health research purposes. BMJ Open 2021 Feb 11;11(2):e040671 [FREE Full text] [doi: 10.1136/bmjopen-2020-040671] [Medline: 33574143 ]

19. Gibbons J, Malouf R, Spitzberg B, Martinez L, Appleyard B, Thompson C, et al. Twitter-based measures of neighborhood sentiment as predictors of residential population health. PLoS One 2019;14(7):e0219550 [FREE Full text] [doi: 10.1371/journal.pone.0219550] [Medline: 31295294]

20. Bender J, Cyr A, Arbuckle L, Ferris L. Ethics and Privacy Implications of Using the Internet and Social Media to Recruit Participants for Health Research: A Privacy-by-Design Framework for Online Recruitment. J Med Internet Res 2017 Apr 06;19(4):e104 [FREE Full text] [doi: 10.2196/jmir.7029] [Medline: 28385682]

21. Salathé M, Freifeld C, Mekaru S, Tomasulo A, Brownstein J. Influenza A (H7N9) and the importance of digital epidemiology. N Engl J Med 2013 Aug 01;369(5):401-404 [FREE Full text] [doi: 10.1056/NEJMp1307752] [Medline: 23822655]

22. Kim Y, Huang J, Emery S. Garbage in, Garbage Out: Data Collection, Quality Assessment and Reporting Standards for Social Media Data Use in Health Research, Infodemiology and Digital Disease Detection. J Med Internet Res 2016 Feb 26;18(2):e41 [FREE Full text] [doi: 10.2196/jmir.4738] [Medline: 26920122]

23. Arigo D, Pagoto S, Carter-Harris L, Lillie SE, Nebeker C. Using social media for health research: Methodological and ethical considerations for recruitment and intervention delivery. Digit Health 2018;4:2055207618771757 [FREE Full text] [doi: 10.1177/2055207618771757] [Medline: 29942634] 
24. 11.2.2 Developing the title and question - JBI Manual for Evidence Synthesis - JBI GLOBAL WIKI. URL: https://wiki. jbi.global/display/MANUAL/11.2.2+Developing+the+title+and+question [accessed 2020-07-07]

25. CADIMA. URL: https://www.cadima.info/ [accessed 2020-07-07]

26. Kohl C, McIntosh EJ, Unger S, Haddaway NR, Kecke S, Schiemann J, et al. Online tools supporting the conduct and reporting of systematic reviews and systematic maps: a case study on CADIMA and review of existing tools. Environ Evid 2018 Feb 1;7(1):8. [doi: 10.1186/s13750-018-0115-5]

27. The donut and Altmetric Attention Score.: Altmetric; 2015 Jul 9. URL: https://www.altmetric.com/about-our-data/ the-donut-and-score/ [accessed 2020-06-30]

28. Didegah F, Bowman TD, Holmberg K. On the differences between citations and altmetrics: An investigation of factors driving altmetrics versus citations for finnish articles. Journal of the Association for Information Science and Technology 2018 Mar 25;69(6):832-843. [doi: 10.1002/asi.23934]

29. Babu R, Vysakh C. Citations v/s Altmetric Attention Score: A Comparison of Top 10 Highly Cited Papers in Nature. 2019. URL: https://digitalcommons.unl.edu/libphilprac/2992 [accessed 2021-01-05]

30. Ortega J. Relationship between altmetric and bibliometric indicators across academic social sites: The case of CSIC's members. Journal of Informetrics 2015 Jan;9(1):39-49. [doi: 10.1016/j.joi.2014.11.004]

31. Costas, Zahedi Z, Wouters P. Do "altmetrics" correlate with citations? Extensive comparison of altmetric indicators with citations from a multidisciplinary perspective. J Assn Inf Sci Tec 2014 Jul 28;66(10):2003-2019. [doi: 10.1002/asi.23309]

32. Ford K, Albritton T, Dunn T, Crawford K, Neuwirth J, Bull S. Youth Study Recruitment Using Paid Advertising on Instagram, Snapchat, and Facebook: Cross-Sectional Survey Study. JMIR Public Health Surveill 2019 Oct 9;5(4):e14080 [FREE Full text] [doi: 10.2196/14080] [Medline: $\underline{\text { 31599739] }}$

33. Colditz J, Chu K, Emery S, Larkin C, James A, Welling J, et al. Toward Real-Time Infoveillance of Twitter Health Messages. Am J Public Health 2018 Aug;108(8):1009-1014. [doi: 10.2105/AJPH.2018.304497] [Medline: 29927648]

34. Fagherazzi G, Ravaud P. Digital diabetes: Perspectives for diabetes prevention, management and research. Diabetes Metab 2019 Sep 19;45(4):322-329. [doi: 10.1016/j.diabet.2018.08.012] [Medline: 30243616]

35. Sinnenberg L, DiSilvestro C, Mancheno C, Dailey K, Tufts C, Buttenheim A, et al. Twitter as a Potential Data Source for Cardiovascular Disease Research. JAMA Cardiol 2016 Dec 01;1(9):1032-1036 [FREE Full text] [doi: 10.1001/jamacardio.2016.3029] [Medline: 27680322]

36. Eichstaedt J, Schwartz H, Kern M, Park G, Labarthe D, Merchant R, et al. Psychological language on Twitter predicts county-level heart disease mortality. Psychol Sci 2015 Feb;26(2):159-169 [FREE Full text] [doi: 10.1177/0956797614557867] [Medline: 25605707]

37. Sharma M, Yadav K, Yadav N, Ferdinand KC. Zika virus pandemic-analysis of Facebook as a social media health information platform. Am J Infect Control 2017 Mar 01;45(3):301-302. [doi: 10.1016/j.ajic.2016.08.022] [Medline: 27776823]

38. Mikal J, Hurst S, Conway M. Ethical issues in using Twitter for population-level depression monitoring: a qualitative study. BMC Med Ethics 2016 Apr 14;17:22 [FREE Full text] [doi: 10.1186/s12910-016-0105-5] [Medline: 27080238]

39. Rudra K, Sharma A, Ganguly N, Imran M. Classifying and Summarizing Information from Microblogs During Epidemics. Inf Syst Front 2018;20(5):933-948 [FREE Full text] [doi: 10.1007/s10796-018-9844-9] [Medline: $\underline{32214879]}$

40. Scanfeld D, Scanfeld V, Larson E. Dissemination of health information through social networks: twitter and antibiotics. Am J Infect Control 2010 Apr;38(3):182-188 [FREE Full text] [doi: 10.1016/j.ajic.2009.11.004] [Medline: 20347636]

41. Watson B, Robinson DHZ, Harker L, Arriola KRJ. The Inclusion of African-American Study Participants in Web-Based Research Studies: Viewpoint. J Med Internet Res 2016 Jun;18(6):e168 [FREE Full text] [doi: 10.2196/jmir.5486] [Medline: 27334683]

42. Davies B, Kotter M. Lessons From Recruitment to an Internet-Based Survey for Degenerative Cervical Myelopathy: Comparison of Free and Fee-Based Methods. JMIR Res Protoc 2018 Feb 05;7(2):e18 [FREE Full text] [doi: 10.2196/resprot.6567] [Medline: 29402760]

43. Wozney L, Turner K, Rose-Davis B, McGrath PJ. Facebook ads to the rescue? Recruiting a hard to reach population into an Internet-based behavioral health intervention trial. Internet Interv 2019 Sep;17:100246 [FREE Full text] [doi: 10.1016/j.invent.2019.100246] [Medline: 31080751]

44. Yuan P, Bare MG, Johnson MO, Saberi P. Using online social media for recruitment of human immunodeficiency virus-positive participants: a cross-sectional survey. J Med Internet Res 2014 May;16(5):e117 [FREE Full text] [doi: 10.2196/jmir.3229] [Medline: 24784982]

45. The rise of social media.: Our World in Data URL: https://ourworldindata.org/rise-of-social-media [accessed 2020-07-06]

46. Clement J. Most popular social networks worldwide 2020, by reach.: Statista; 2020 Jun 23. URL: https://www.statista.com/ statistics/274773/global-penetration-of-selected-social-media-sites/ [accessed 2020-07-06]

47. Anderson M, Jiang J. Teens, Social Media \& Technology. 2018. URL: https://www.pewresearch.org/internet/2018/05/31/ teens-social-media-technology-2018/ [accessed 2020-07-06]

48. Rait M, Prochaska J, Rubinstein M. Recruitment of adolescents for a smoking study: use of traditional strategies and social media. Transl Behav Med 2015 Sep;5(3):254-259. [doi: 10.1007/s13142-015-0312-5] [Medline: 26327930] 
49. Schwinn T, Hopkins J, Schinke S, Liu X. Using Facebook ads with traditional paper mailings to recruit adolescent girls for a clinical trial. Addict Behav 2017 Feb;65:207-213 [FREE Full text] [doi: 10.1016/j.addbeh.2016.10.011] [Medline: 27835860]

50. Salathé M. Digital Pharmacovigilance and Disease Surveillance: Combining Traditional and Big-Data Systems for Better Public Health. J Infect Dis 2016 Dec 01;214(suppl_4):S399-S403 [FREE Full text] [doi: 10.1093/infdis/jiw281] [Medline: 28830106]

51. Leach LS, Butterworth P, Poyser C, Batterham PJ, Farrer LM. Online Recruitment: Feasibility, Cost, and Representativeness in a Study of Postpartum Women. J Med Internet Res 2017 Mar 08;19(3):e61 [FREE Full text] [doi: 10.2196/jmir.5745] [Medline: 28274906$]$

52. Chu J, Snider C. Use of a social networking web site for recruiting Canadian youth for medical research. J Adolesc Health 2013 Jun;52(6):792-794. [doi: 10.1016/j.jadohealth.2012.12.002] [Medline: 23352727]

53. Cowie JM, Gurney ME. The Use of Facebook Advertising to Recruit Healthy Elderly People for a Clinical Trial: Baseline Metrics. JMIR Res Protoc 2018 Jan 24;7(1):e20. [doi: 10.2196/resprot.7918] [Medline: 29367186]

54. Ramo DE, Prochaska JJ. Broad reach and targeted recruitment using Facebook for an online survey of young adult substance use. J Med Internet Res 2012 Feb 23;14(1):e28 [FREE Full text] [doi: 10.2196/jmir.1878] [Medline: 22360969]

55. Arcia A. Facebook Advertisements for Inexpensive Participant Recruitment Among Women in Early Pregnancy. Health Educ Behav 2014 Jun;41(3):237-241 [FREE Full text] [doi: 10.1177/1090198113504414] [Medline: 24082026]

56. Batterham P. Recruitment of mental health survey participants using Internet advertising: content, characteristics and cost effectiveness. Int J Methods Psychiatr Res 2014 Jun;23(2):184-191 [FREE Full text] [doi: 10.1002/mpr.1421] [Medline: 24615785]

57. Garland SM, Wark JD, Tabrizi SN, Jayasinghe Y, Moore E, Fletcher A, et al. P1-S4.32 Recruiting via social networking sites for sexual health research (assessing chlamydia and HPV knowledge). Sexually Transmitted Infections 2011 Jul 10;87(Suppl 1):A173-A174. [doi: 10.1136/sextrans-2011-050108.176]

58. Pedersen ER, Helmuth ED, Marshall GN, Schell TL, PunKay M, Kurz J. Using facebook to recruit young adult veterans: online mental health research. JMIR Res Protoc 2015 Jun 01;4(2):e63 [FREE Full text] [doi: 10.2196/resprot.3996] [Medline: 26033209]

59. Ramo D, Rodriguez T, Chavez K, Sommer M, Prochaska J. Facebook Recruitment of Young Adult Smokers for a Cessation Trial: Methods, Metrics, and Lessons Learned. Internet Interv 2014 Apr;1(2):58-64 [FREE Full text] [doi:

10.1016/j.invent.2014.05.001] [Medline: 25045624]

60. Youn SJ, Trinh N, Shyu I, Chang T, Fava M, Kvedar J, et al. Using online social media, Facebook, in screening for major depressive disorder among college students. International Journal of Clinical and Health Psychology 2013 Jan;13(1):74-80. [doi: 10.1016/s1697-2600(13)70010-3]

61. Santillana M, Nguyen A, Dredze M, Paul M, Nsoesie E, Brownstein J. Combining Search, Social Media, and Traditional Data Sources to Improve Influenza Surveillance. PLoS Comput Biol 2015 Oct;11(10):e1004513 [FREE Full text] [doi: 10.1371/journal.pcbi.1004513] [Medline: 26513245]

62. Golder S, Norman G, Loke YK. Systematic review on the prevalence, frequency and comparative value of adverse events data in social media. Br J Clin Pharmacol 2015 Oct;80(4):878-888 [FREE Full text] [doi: 10.1111/bcp.12746] [Medline: 26271492]

63. Tricco A, Zarin W, Lillie E, Jeblee S, Warren R, Khan P, et al. Utility of social media and crowd-intelligence data for pharmacovigilance: a scoping review. BMC Med Inform Decis Mak 2018 Jun 14;18(1):38 [FREE Full text] [doi: 10.1186/s12911-018-0621-y] [Medline: 29898743]

64. Pappa D, Stergioulas LK. Harnessing social media data for pharmacovigilance: a review of current state of the art, challenges and future directions. Int J Data Sci Anal 2019 Feb 12;8(2):113-135 [FREE Full text] [doi: 10.1007/s41060-019-00175-3]

65. Corley CD, Cook DJ, Mikler AR, Singh KP. Using Web and social media for influenza surveillance. Adv Exp Med Biol 2010;680:559-564 [FREE Full text] [doi: 10.1007/978-1-4419-5913-3 61] [Medline: 20865540]

66. Brownstein JS, Freifeld CC, Madoff LC. Digital disease detection--harnessing the Web for public health surveillance. N Engl J Med 2009 May 21;360(21):2153-2157 [FREE Full text] [doi: 10.1056/NEJMp0900702] [Medline: 19423867]

67. Robertson C, Yee L. Avian Influenza Risk Surveillance in North America with Online Media. PLoS One 2016;11(11):e0165688 [FREE Full text] [doi: 10.1371/journal.pone.0165688] [Medline: 27880777]

68. Paul MJ, Dredze M, Broniatowski D. Twitter improves influenza forecasting. PLoS Curr 2014 Oct 28;6:ecurrents.outbreaks.90b9ed0f59bae4ccaa683a39865d9117 [FREE Full text] [doi: 10.1371/currents.outbreaks.90b9ed0f59bae4ccaa683a39865d9117] [Medline: 25642377]

69. Nikfarjam A, Sarker A, O'Connor K, Ginn R, Gonzalez G. Pharmacovigilance from social media: mining adverse drug reaction mentions using sequence labeling with word embedding cluster features. J Am Med Inform Assoc 2015 May;22(3):671-681 [FREE Full text] [doi: 10.1093/jamia/ocu041] [Medline: 25755127]

70. O'Dea B, Achilles MR, Larsen ME, Batterham PJ, Calear AL, Christensen H. The rate of reply and nature of responses to suicide-related posts on Twitter. Internet Interv 2018 Sep;13:105-107 [FREE Full text] [doi: 10.1016/j.invent.2018.07.004] [Medline: 30206524] 
71. Rong J, Michalska S, Subramani S, Du J, Wang H. Deep learning for pollen allergy surveillance from twitter in Australia. BMC Med Inform Decis Mak 2019 Nov 08;19(1):208 [FREE Full text] [doi: 10.1186/s12911-019-0921-x] [Medline: 31699071]

72. Conway M, Hu M, Chapman W. Recent Advances in Using Natural Language Processing to Address Public Health Research Questions Using Social Media and ConsumerGenerated Data. Yearb Med Inform 2019 Aug;28(1):208-217 [FREE Full text] [doi: 10.1055/s-0039-1677918] [Medline: 31419834]

73. Allen C, Tsou M, Aslam A, Nagel A, Gawron JM. Applying GIS and Machine Learning Methods to Twitter Data for Multiscale Surveillance of Influenza. PLoS One 2016;11(7):e0157734 [FREE Full text] [doi: 10.1371/journal.pone.0157734] [Medline: 27455108]

74. Ahne A, Orchard F, Tannier X, Perchoux C, Balkau B, Pagoto S, et al. Insulin pricing and other major diabetes-related concerns in the USA: a study of 46407 tweets between 2017 and 2019. BMJ Open Diabetes Res Care 2020 Jun 04;8(1):e001190 [FREE Full text] [doi: 10.1136/bmjdrc-2020-001190] [Medline: $\underline{\text { 32503810] }}$

75. Samaras L, García-Barriocanal E, Sicilia MA. Comparing Social media and Google to detect and predict severe epidemics. Sci Rep 2020 Mar 16;10(1):4747. [doi: 10.1038/s41598-020-61686-9] [Medline: 32179780]

76. Nguyen Q, Li D, Meng H, Kath S, Nsoesie E, Li F, et al. Building a National Neighborhood Dataset From Geotagged Twitter Data for Indicators of Happiness, Diet, and Physical Activity. JMIR Public Health Surveill 2016 Oct 17;2(2):e158 [FREE Full text] [doi: 10.2196/publichealth.5869] [Medline: 27751984]

77. Aramburu MJ, Berlanga R, Lanza I. Social Media Multidimensional Analysis for Intelligent Health Surveillance. Int J Environ Res Public Health 2020 Mar 28;17(7):2289 [FREE Full text] [doi: 10.3390/ijerph17072289] [Medline: 32231152]

78. Bravo C, Hoffman-Goetz L. Tweeting About Prostate and Testicular Cancers: What Are Individuals Saying in Their Discussions About the 2013 Movember Canada Campaign? J Cancer Educ 2016 Sep;31(3):559-566. [doi: 10.1007/s13187-015-0838-8] [Medline: 25903054]

79. Aleksina A, Akulenka S, Lublóy Á. Success factors of crowdfunding campaigns in medical research: perceptions and reality. Drug Discov Today 2019 Jul;24(7):1413-1420. [doi: 10.1016/j.drudis.2019.05.012] [Medline: $\underline{31132416]}$

80. Ahmad A, Murad H. The Impact of Social Media on Panic During the COVID-19 Pandemic in Iraqi Kurdistan: Online Questionnaire Study. J Med Internet Res 2020 May 19;22(5):e19556 [FREE Full text] [doi: 10.2196/19556] [Medline: 32369026]

81. Cinelli M, Quattrociocchi W, Galeazzi A, Valensise C, Brugnoli E, Schmidt A, et al. The COVID-19 social media infodemic. Sci Rep 2020 Oct 06;10(1):16598 [FREE Full text] [doi: 10.1038/s41598-020-73510-5] [Medline: 33024152]

82. González-Padilla DA, Tortolero-Blanco L. Social media influence in the COVID-19 Pandemic. Int Braz J Urol 2020 Jul;46(suppl.1):120-124 [FREE Full text] [doi: 10.1590/S1677-5538.IBJU.2020.S121] [Medline: 32550706]

83. Rovetta A, Bhagavathula A. Global Infodemiology of COVID-19: Analysis of Google Web Searches and Instagram Hashtags. J Med Internet Res 2020 Aug 25;22(8):e20673 [FREE Full text] [doi: 10.2196/20673] [Medline: $\underline{32748790]}$

84. Li J, Xu Q, Cuomo R, Purushothaman V, Mackey T. Data Mining and Content Analysis of the Chinese Social Media Platform Weibo During the Early COVID-19 Outbreak: Retrospective Observational Infoveillance Study. JMIR Public Health Surveill 2020 Apr 21;6(2):e18700 [FREE Full text] [doi: 10.2196/18700] [Medline: $\underline{\text { 32293582] }}$

85. Ali S, Foreman J, Capasso A, Jones A, Tozan Y, DiClemente R. Social media as a recruitment platform for a nationwide online survey of COVID-19 knowledge, beliefs, and practices in the United States: methodology and feasibility analysis. BMC Med Res Methodol 2020 May 13;20(1):116 [FREE Full text] [doi: 10.1186/s12874-020-01011-0] [Medline: 32404050]

86. Karmaker SS, Bindschadler V, Zhai C, Gunter C. NRF: A Naive Re-identification Framework. 2018 Oct Presented at: Workshop on Privacy in the Electronic Society at the Computer and Communications Security Conference (WPES@CCS), 2018; October 2018; Toronto, Canada. [doi: 10.1145/3267323.3268948]

87. Hunter RF, Gough A, O'Kane N, McKeown G, Fitzpatrick A, Walker T, et al. Ethical Issues in Social Media Research for Public Health. Am J Public Health 2018 Mar;108(3):343-348. [doi: 10.2105/AJPH.2017.304249] [Medline: 29346005]

88. Wekerle C, Vakili N, Stewart S, Black T. The utility of Twitter as a tool for increasing reach of research on sexual violence. Child Abuse Negl 2018 Nov;85:220-228. [doi: 10.1016/j.chiabu.2018.04.019] [Medline: 29778296]

89. Hammer M. Ethical Considerations When Using Social Media for Research. Oncol Nurs Forum 2017 Jul 01;44(4):410-412 [FREE Full text] [doi: 10.1188/17.ONF.410-412] [Medline: 28632249]

90. McKee R. Ethical issues in using social media for health and health care research. Health Policy 2013 May;110(2-3):298-301. [doi: 10.1016/j.healthpol.2013.02.006] [Medline: $\underline{23477806]}$

91. Wisk L, Nelson E, Magane K, Weitzman E. Clinical Trial Recruitment and Retention of College Students with Type 1 Diabetes via Social Media: An Implementation Case Study. J Diabetes Sci Technol 2019 May;13(3):445-456 [FREE Full text] [doi: 10.1177/1932296819839503] [Medline: $\underline{31010315}$ ]

92. Child R, Mentes J, Pavlish C, Phillips L. Using Facebook and participant information clips to recruit emergency nurses for research. Nurse Res 2014 Jul;21(6):16-21. [doi: 10.7748/nr.21.6.16.e1246] [Medline: 25059083]

93. Hu J, Wong K, Wang Z. Recruiting migrants for health research through social network sites: an online survey among chinese migrants in australia. JMIR Res Protoc 2015 Apr 27;4(2):e46 [FREE Full text] [doi: 10.2196/resprot.3960] [Medline: 25917837] 
94. Social media guidelines for researchers - Staff home, The University of York. URL: https://www.york.ac.uk/staff/research/ governance/research-policies/social-media/ [accessed 2020-07-08]

95. Townsend L, Wallace C. Social Media Research: A Guide to Ethics. URL: https://www.gla.ac.uk/media/Media 487729 smxx. pdf [accessed 2020-07-01]

96. Schillinger D, Chittamuru D, Ramírez AS. From "Infodemics" to Health Promotion: A Novel Framework for the Role of Social Media in Public Health. Am J Public Health 2020 Sep;110(9):1393-1396. [doi: 10.2105/AJPH.2020.305746] [Medline: 32552021]

97. Guidelines for Research Involving Social Media.: Ryerson University URL: https://www.ryerson.ca/content/dam/research/ documents/ethics/guidelines-for-research-involving-social-media.pdf [accessed 2020-07-17]

98. Guidelines for Obtaining Consent and Assent.: Ryerson University URL: https://www.ryerson.ca/content/dam/research/ documents/ethics/guidelines-for-obtaining-assent-and-consent.pdf [accessed 2020-07-17]

\author{
Abbreviations \\ MeSH: Medical Subject Headings \\ PRISMA-ScR: Preferred Reporting Items for Systematic Reviews and Meta-analyses Extension for Scoping \\ Reviews \\ SM: social media
}

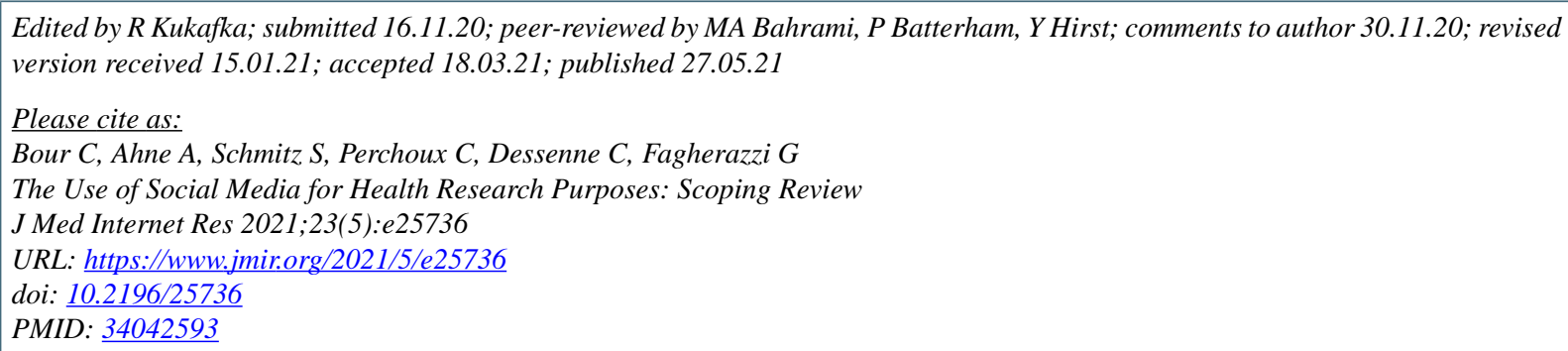

(C) Charline Bour, Adrian Ahne, Susanne Schmitz, Camille Perchoux, Coralie Dessenne, Guy Fagherazzi. Originally published in the Journal of Medical Internet Research (https://www.jmir.org), 27.05.2021. This is an open-access article distributed under the terms of the Creative Commons Attribution License (https://creativecommons.org/licenses/by/4.0/), which permits unrestricted use, distribution, and reproduction in any medium, provided the original work, first published in the Journal of Medical Internet Research, is properly cited. The complete bibliographic information, a link to the original publication on https://www.jmir.org/, as well as this copyright and license information must be included. 